\title{
Notes and Documents
}

\author{
THE FIELD OF CANNAE.
}

A visir paid to the field of Cannao during the course of last spring has recalled my attention to the question as to the side of the Aufidus on which the fight took place. I have looked into the authorities, and I shall offer a lew observations on the subject. $I$ have little to add to the general description of the site given by Mr. Strachan Davidson in his essay on the 'Battle of Caunae,' and his additional note on Cannae in his 'Selections from Polybius;' and for the better understanding of what I am about to say I would refer my readers to the map in that volume. Roughly spealing, the river in its devions course is the dividing line betwcen two plains, the one to the north-west being the lower in point of elevation and the more level in point of surface; the one to the sonth-east being at a higher level and less even in surface, but both sufficiently level for an engagement even of caralry. In point of fact the escarpment in which the south-eastern plain ends north- westwards is the edge in that direction of the pliocene strata, and the plain to the north is pleistocene, and therefore of a later date. The water bas, as is so often the case, taken its course nearly along the line of junction of two different strata, though the Aufidus has probably. left in most places a small area of pleistocene between it and the foot of the earlier rock. Here, as in other cases, geology has something to say to history.

Polybius and Appian are clear on two points, viz. first, that the Romans faced south, and the Carthaginians consequently north; and secondly, that the Romans rested on the river with their right wing and the Carthaginians with their left wing. Polybius sass of

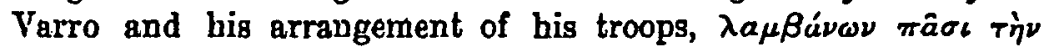

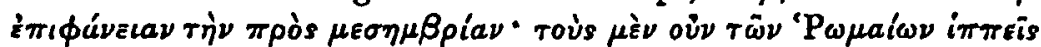

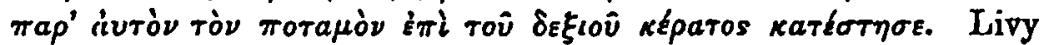
is equally clear: the generals in dextro cornu (id erat fumini propius) Romanos equites locant ... Romanis in meridiem, Poenis in septentrionem rersis. And Appinn, though silent as to the river, agrees in placing the Carthaginians as facing the north.

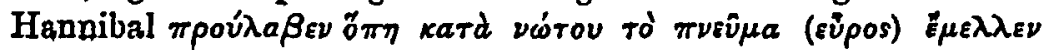




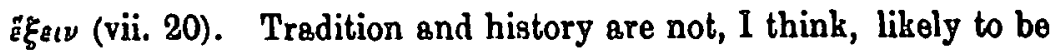
wrong on these broad facts of the case.

Take as data the statements that the Romans fought with their right wing resting on the river, and with their faces furned southward, and the Carthaginians in the opposite direction : is seemed to me, ss I stood on the ground, to be impossible to place the battle-field anywhere but on the southern and more elevated plateau ; the notion that the ormies could have been engeged within any bend of the river, or in the norrow strip between the river and the escarpment, was, I thought, impossible. The sccount in Polybius seems to make the matter clear; and if it were not impertinent to offer any opinion on a question of topography on which Mr. Strachan Devideon and Mr. Tozer are agreed, I should venture to express my concurrence in the plan of the battle as shown by Mr. Strachen Davidson, subject to one small point. I think it probable that the smaller camp of the Romans was not on the southern plateau, but somewhere on the narrow strip of low land to the south of the river, between it and the foot of the escarpment, becsuse it appears to me that a small camp close to the river would have best subserved the two objects which the Romans had in establishing it across the river, viz. giving assistance to the Roman foraging parties crossing over from the northern camp and checking the passage northward of the Carthaginien foragers (Polgb. iii. 110).

Bir. Strachan Davidson hes not unnaturally confined his discussion slmost ontirely to the sccount of the bsttle given by his author, Yolybius; and there can, I suppose, be no question but that of all the accounts which we possess that is far the most authentic. But we have, besides, the accounts of Livy, of Appian, and of Plutarch. The last may be neglected as too rague to be of any use, but the other two contain statements with regard to the battle not to be found in Polybius. Even if these statements were known to Polybius, and were rejected by him, and even if the accounts of Livy and Appian are less clear and consistent than that of Polybius, it does not follow that these statements may not hare a foundation in fact; it may, therefore, it seems to me, be worth while to inquire how far these narratives are consistent with the theory of the southern location of the field of battle.

The history of the battle as understood by Livy (lib. zxii) seems to me to be this: Livy knows nothing of the capture of Cannae by Hannibal. Hanuibal is represented as fixing his camp near Cannae (prope eum ricum). This camp must, I think, hare been on the northern side of the river, because when the Romans established a camp on the south side it is said to have had an access to the river free from the interference of the Cartheginians. The Romans follow Bannibal and form two camps, the larger 
on the north and the smaller on the south side of the stream. Hannibal endeavours to bring on a general engagement on the northern plain, but without success; and then sends his Numidian forces across the river to harsss the men from the lesser crmp in getting Friter from the river. On the following duy, the commond boing with Varro, that genersl crosses the river to the south with his forces from the lorger csmp, and joins with those from the smoller csmp, and drsws up his forces with his right wing resting on the river. Honnibal in the early morning crosses the river from the north to the south (Annibal prima luce . . . transgresoue flumen), and drews up bis line of battle with his left wing on the river (prope sipam laero in cornu). The Romans had thus their faces turned southward and the Carthaginians northward, so that the south-east wind, the Volturnus, blew the dust in the faces of the Romens. This narrative may be deficient in omitting to atate that Hannibal first constructed a camp on the south aide of the river, and moved from thence to s camp on the northern side, ss Polybius tells us; bus it appears to mo to be an intelligent narrative, and one which is consistent, and consistent only, with the battle having been fought on the southern plain; for, looking at the course of the Aufidus, is is easy on the southern platesu to draw up en armey facing sousth with its right wing resting on the river, but iupossible so to drew np an ormy on the northern plain : on that plain an army facing south must have had ils left wing, if either, resting on the river.

I turn now to the account given by Appian, whether on tho suthority of Fabius Pictor or of whot other earlier writer we know not. He certainly has not \& very clest notion of the course of the Aufidus, for (in lib. vii. 'De Bello Annibalico,' c. 16) he seams to conceive of it as flowing near Geronium, from which it is, in sact, far distant. He knows nothing of the capture of Cannse by Hannibal, but, on the contrasy, represents some of the Roman fugitires after the bottle as Aging thither, which of course iroplies that it was in the hands of the Romens. The first move thithes

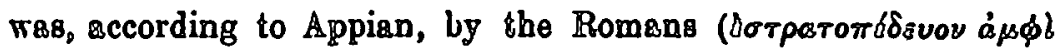

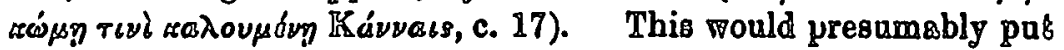
the camp on the sonth side of the river, for so and so only could the Romans get the protection arosded by the escarpment. Hannibal encomps over against them; and then follows an offer of an angegement by Hannibal snd snother by the Romsns, neither of which is accepted by the enemy. On the following day they both descend on to

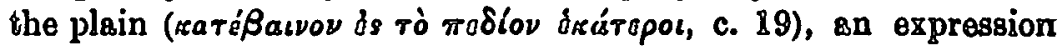
which it must be admitted seems rather to snit the northern then tho southern plsin; and there is as yet in the narretive of Appian no suggestion of the nesrness of the Aufidus or of the opposing forces being othermise than on the same side of the river. Then Appian 
states that Hennibal drew up his troops 80 as to have the usual south-esst wind (eipos) in the back of his troops. Now, unless the Romens had not only gone to the north of the river but gone so fas north ss to sllow Hannibal to place his whole army between them and the Aufidus, the position thus assumed by Maraibal mose hqve been on the southern plain. In the next plece he atares blast Hennibal placed some cevelry and light-armed troops in s place of ambush on a hill covered with irees and intersected by gorges (is

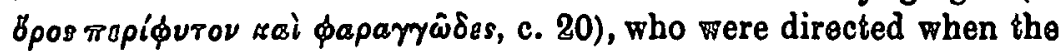
battle was going on to etteck the resr of the Romsns. Now it would be, I think, sbsolutely in vain to seets for any position of sll corresponding with this account if the engegement wes on the northern plain; but the broken gullies of the escarpment of the southern plain appess to bo described by the words of Appian which I have quoted; and troops which might well be concesled on this broken ground would, of course, be in the rear of the Roman atation near Cannese. These incidents, which sre to by no mesns im. probable ones, seem strongly to lesd to the view that even on the reading of Appian slone, the fight took place on the southern pleteau.

It h\&s been suggested, as an objection to the loregoing con. clusion, that if the battle hed taken place on the southern plateav, a desperate effort of the Romans to escape down the escarpment and across the Aufdus would have been the moin feature of the after part of the engagement. But agrinst this there are seversl considerations to be set. In the first place the great body of the Romans seem to have broten through the weak centre of tho Carthaginians, and to have boen destroyed from the seas by the closing in of the Carthaginian wings babind them. All hope of escepe northward was thus shut out to these troops, and accordingly such as escaped made for Canusium and Venusis, as the nearest places of safety, and these were both, liko the routed Romans, to the south of the Aufidus. Agrin, to such of the Roman forces 8 were not enclosed by the Cartbaginisas, the Romen comp offered a far more aitructive place of reluge then the open plain to the north. Besides which, according to Appian, Hannibal bad already provided for two things-the placing of an ambush in the broken ground, which I conceire to heve been the gullies of the escarpment, and the presence of a body of Celtiberiane in the rear of the Romans through a mise. They had apposred to go over to the Romani on the fold, had been put prisonere in the resp, and when the bettle went sgainst the Romans they rose and did execution with the ohort deggers which they had concesled beneath their closks. These atrotagems of Kannibal, if truly reposted by Appisn, would sssist in shutting ous the Romenns from ang chence of escaping towasds the rirer. 
One fact may be mentioned in reference to Cannae, though it has no bearing on the question of the site of the battle-field. Just below the Mrasseris of Cannae, in the broken gully which leads from the higher level to the river, our attention ros called to \& Romen milestone, to all appearence nearly in situ. It bore the following inscription, which has, I dare say, been copied and published bolore:-

\section{LXXIX}

IMP. CAEgAR

DIVI NEBVAE $F$.

NERVA TRAJANUB

AUG. GERM. DACIC.

PONT. MAX.

TR. POT. XIII, IMP. VX. cos. V.

PP

VIAM A BENEVENTO

BRUNDIBIUM PRCU\%.

SUA YECIT

The presence of this milesione on this spot seems to imply that Trajan's new road to Brindiai must bave passed by or through the fown of Connese and down the gully towards the river. This is, however, inconsistent with the generally received view that Trajen's rosd crossed the Aufidus near Canusium, and therefore sbove Cannse, and kept thence towards Barium to the west and south of that town. It is moreover difficult to make the position of shis atone harmonise with 'the eighty-fires Columna milliaris inscribed with the namo of Trajen ' which Swinburne mentions ss found by him the town of tsa Cerignols ("Travels in the Tro Sicilies,' and edition, i. 258).

EuWARd Fry.

THE CONAGE OF THE THBEE RDWARDS.

This attompts hitherto made to separate the coins of the reigns of IEdward I, Edward II, and Edward III, have been based upon numismatic considerations. Of the details of such attempts only numismatiats can speak; bat the writers of this note, working from the historical side, have been led to the conclusion that the classification of coins given in such books as Ruding's 'Annols of the Coinage' and Kenyon's edition of Howkins's 'English Silver Coing' is neither complete nor in all cases correct. The following table, drawn up by Messrs. A. Hughes, C. G. Crump, and C. Johnson from the accounts of the wardens of the Mint, enrolled upon the pipe rolls, aims at ehowing sll the types of coin issued by the Mrint during these reigns, without reference to changes of impression, is jpoins on which that suthority affords no evidence. In this table 